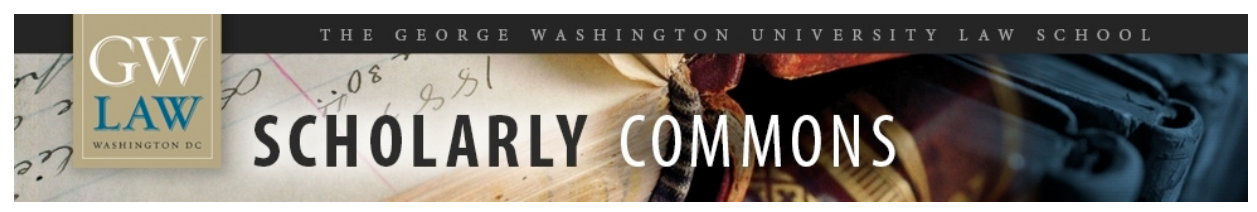

GW Law Faculty Publications \& Other Works

Faculty Scholarship

2010

\title{
The First Amendment Issue of Our Time
}

Dawn C. Nunziato

George Washington University Law School, dnunziato@law.gwu.edu

Follow this and additional works at: https://scholarship.law.gwu.edu/faculty_publications

Part of the Law Commons

\section{Recommended Citation}

Nunziato, Dawn Carla, The First Amendment Issue of Our Time (2010). 29 Yale Law and Policy Review: Inter Alia (Dec. 2010).; GWU Law School Public Law Research Paper No. 2017-47; GWU Legal Studies Research Paper No. 2017-47. Available at SSRN: https://ssrn.com/abstract=3000594

This Article is brought to you for free and open access by the Faculty Scholarship at Scholarly Commons. It has been accepted for inclusion in GW Law Faculty Publications \& Other Works by an authorized administrator of Scholarly Commons. For more information, please contact spagel@law.gwu.edu. 


\section{THE FIRST AMENDMENT ISSUE OF OUR TIME Dawn C. Nunziato ${ }^{\mathrm{a} 1}$}

\section{INTRODUCTION}

Here we go, once more unto the breach, to face yet another battle in the near decade-long war over net neutrality. Some of the combatants have changed, and their positions have shifted slightly, but today we find essentially the same interests represented and the same arguments advanced. On one side, the major cable, Digital Subscriber Line (DSL), and wireless broadband providers continue to argue against increasing the Federal Communication Commision's (FCC) authority over how these providers manage the flow of information through their pipes. On the other side, we have content providers, Internet users, and--this time--the FCC, contending that the government has the power to protect the free flow of information on the Internet. In 2002, the FCC under President George W. Bush and then Chairman Kevin Martin embarked on a course of extremely light (which turned out to be nonexistent) ${ }^{1}$ regulatory oversight of broadband providers. The Obama administration, with Chairman Julius Genachowski now at the helm, is attempting to reverse this course and impose a meaningful net neutrality mandate on broadband providers. In this iteration, not only has the FCC switched sides, but, to keep things interesting, Google and Verizon-- typically on opposite sides of the net neutrality debate--have joined together to find common ground and have proposed a compromise position.

Many of the issues are nuanced, yet the general contours of the arguments are relatively straightforward. On the one hand, the broadband providers' argument continues to proceed something like this: Trust the market. Any imperfections in the market or barriers to free and open Internet communications will be cured by the market itself. The market is robust and has thrived thus far without regulation, and the Internet will only be hampered by regulation. There is simply no need for net neutrality regulation because there is hardly any evidence that broadband providers have discriminated against content or applications (and Comcast had good reasons for blocking BitTorrent traffic). Furthermore, regulation of broadband providers will violate those providers' First Amendment rights as speakers to select, edit, block, or favor the content of their choosing. ${ }^{2}$

In response, the proponents of net neutrality regulation such as myself argue that broadband providers serve as increasingly important conduits for our communications. ${ }^{3}$ This is especially true with respect to those providers' ability to manage the "transmission component" of broadband communications--the part the FCC now seeks to regulate. Conduits for communications--which we call "common carriers," such as telephone companies, the postal service, and telegraph companies of old--have long been under a legal obligation not to discriminate against the communications they are charged with carrying. The telephone company cannot refuse to connect your call because your conversation is racy, ${ }^{4}$ nor can the postal service refuse to deliver your mail because it contains unpopular political propaganda. ${ }^{5}$ This basic duty not to discriminate is imposed regardless of the existence of monopoly control by communications conduits. We have learned over the past century not to entrust our free speech interests to "the market." Rather, we regulate these conduits for communication because doing so is necessary to ensure the free flow of information. The relevant free speech interests at issue here are not those of the broadband provider (which are virtually nonexistent) but those of members of the public whose communications must be facilitated free of discrimination or censorship in order for democratic self-government to fun

Notably, both sides of the net neutrality debate invoke free speech in support of their cause. As a result, the net neutrality battle has turned into what has been called "the First Amendment issue of our time."” In what follows, I explore some of the latest contours of the net neutrality debate, with an eye toward evaluating the First Amendment and free speech implications of both sides' arguments. Part I examines the specifics of the approaches to net neutrality regulation recently proposed by the FCC and the Verizon-Google team. In Part II, I critique broadband providers' arguments that net neutrality regulation would violate their First Amendment rights. Part III argues that proposed transparency-only requirements for wireless broadband providers are insufficient to protect our full range of free speech interests. And Part IV proposes a framework for regulating "specialized" online services that is informed by the First Amendment’s public forum doctrine.

\section{THE LATEST BATTLE LINES}


Over the past several months, we have seen a whirlwind of net neutrality developments. In the wake of April's Comcast decision, in which the United States Court of Appeals for the District of Columbia Circuit rejected the FCC's assertion of "ancillary" authority to censure Comcast for impeding the free flow of information on the Internet," the FCC floated a new approach to regulating broadband in an attempt to reassert its power in this arena. ${ }^{8}$ In its "Third Way" proposal released in June, the Agency announced its intention to change directions from the deregulatory course it began in 2002 and suggested imposing a minimal nondiscrimination mandate upon broadband providers. Specifically, the FCC gave notice of its plan to reclassify the transmission component of broadband as a regulated "telecommunications service" under Title II of the Communications Act, rather than as an unregulated "information service." ${ }^{\prime}$ The FCC's approach is intended to strike a balance between two extremes--on the one hand, exempting broadband providers from any meaningful nondiscrimination rules (the status quo), and on the other, fully reclassifying broadband services as "telecommunications services" and imposing the full (and onerous) slate of common carrier regulations on them. The Commission's Third Way approach would conceptually bifurcate the services offered by broadband providers into (1) a transmissions component, through which providers facilitate the transfer of bits, pure and simple, from individuals' computers to and from the Internet, and (2) additional services offered by broadband providers, like technical support and e-mail account service. It would impose a nondiscrimination mandate only on the transmissions component. This reclassification would essentially mean that broadband providers would be treated in some respects as common carriers--as are telephone services and the postal service-and that they would be required to facilitate the transmission of all legal communications in a nondiscriminatory manner. But, under "Third Way," the FCC would refrain from applying a number of Title II's forty-eight common-carrier regulations to broadband providers, and would apply only a handful of sections necessary to prohibit discriminatory practices, including Sections 201, 202, and 208, of the Communications Act. ${ }^{10}$

This proposed mandate is only part of the story. The FCC has suggested that this nondiscrimination mandate should apply only to the transmissions component of wireline or fixed broadband providers in their provision of general broadband Internet access. The Commission would excuse mobile wireless broadband (iPhones' and Androids' Internet access, for example) from the nondiscrimination requirement. The FCC has also suggested that, while a nondiscrimination mandate should apply to the provision of general wireline broadband Internet access, this mandate should not necessarily apply to the provision of specialized services--those with a different scope or purpose than general broadband Internet access service-such as premium online gaming services or health care monitoring services. ${ }^{11}$ This three-part approach was also more or less espoused by Google and Verizon in their controversial Legislative Framework Proposal released in August. ${ }^{12}$ Those companies proposed that general fixed or wireline broadband Internet access (cable broadband and DSL) should be subject to a (qualified) ${ }^{13}$ nondiscrimination mandate but that this mandate should not apply to "additional online services" that are "distinguishable in scope and purpose from broadband Internet access." ${ }^{14}$ Nor would the Verizon-Google nondiscrimination mandate apply to mobile wireless broadband. Under their proposal, wireless broadband providers would be subject only to a transparency requirement, requiring such providers merely to disclose information to their users regarding whatever discriminatory practices they may adopt. ${ }^{15}$ In what follows, I explore the free speech implications of the arguments for and against this proposed three-part regulatory approach, i.e.,

(1) a nondiscrimination mandate imposed on general wireline and fixed broadband services;

(2) a transparency-in-discrimination mandate--with no corresponding nondiscrimination mandate--imposed on mobile wireless broadband; and

(3) no nondiscrimination mandate imposed on "specialized" or "additional online" services provided by broadband providers.

\section{BROADBAND PROVIDERS ARE PRIMARILY CONDUITS NOT SPEAKERS AND ARE PROPERLY SUBJECT TO A NONDISCRIMINATION MANDATE}

The FCC's proposal to reverse its course of the past decade and reclassify the transmission component of general wireline broadband Internet access is a controversial but necessary fix for the problem created by the FCC's own hand in 2002 when it chose to exempt cable broadband providers from meaningful nondiscrimination regulation. Although this proposal will continue to face strong opposition from broadband providers on a variety of fronts, in what follows, I address specifically the First Amendment arguments put forth by opponents of the proposal. 
Broadband providers have long clung to the argument that they enjoy the First Amendment right to censor the content of their choosing and that a nondiscrimination mandate would violate their free speech rights. Even while claiming that they do not actually discriminate against expression and that they in fact allow for the free flow of all types of information through their pipes, ${ }^{16}$ they claim that their primary role for purposes of First Amendment analysis is similar to that of a newspaper editor-that of a selector or editor of the Internet's content and as a speaker in their own right, not as a conduit for the communications of others. They characterize their role as such to champion their right to censor the content of their choosing and to shore up their First Amendment rights under existing precedent. ${ }^{17}$ Verizon, for example, characterizes the provision of broadband Internet access as first and foremost "the microphone through which broadband Internet access providers speak," 18 and claims that "Verizon's position under the First Amendment as a broadband Internet access provider is no different than a newspaper publisher's" ${ }^{19}$-that is, as an editor or selector of content. The Supreme Court has held that government interference with newspaper publishers' discretion, such as by requiring newspapers to publish content not of their choosing, violates the newspapers' First Amendment rights. ${ }^{20}$ Verizon argues that the FCC's proposed "regulation of broadband networks today presents the same speech concerns that regulation of newspapers has historically created."21

Broadband providers' efforts to cast themselves primarily in the role of speakers or editors in opposing the nondiscrimination mandate for the provision of general broadband services misconstrues the realities of broadband Internet access and misinterprets First Amendment case law and policy. In providing general broadband Internet access--as opposed to specialized or additional services--broadband providers like Verizon and Comcast predominantly function for First Amendment purposes as conduits for the speech of others, not as speakers or editors in their own right. Recall that the proposed regulation at issue targets the transmission component of general broadband service, not the add-on or specialized services offered by such providers. Broadband providers' primary function with respect to the transmission component of their general broadband Internet access is to serve as conduit or pipeline for the speech of others. When we analyze where on the First Amendment spectrum-- pure conduit versus pure editor and selector--broadband providers fall with respect to the transmission component of general broadband Internet access, it becomes clear that this function places them much closer to the conduit end than the editor end. Although Comcast and Verizon, for example, may exercise some editorial discretion and selectivity in providing additional online or specialized services, as in email or security or gaming services, their predominant function in providing the transmission component for general broadband Internet access is that of serving as a conduit for the expression of Internet users. Furthermore, unlike in the scenario in which the Court recognized newspapers' First Amendment right not to be associated with speech that was not of their choosing, there is virtually no risk that the content required to be facilitated via a broadband provider's pipes under the nondiscrimination mandate would ever be attributed to the broadband provider itself. ${ }^{22}$

Even assuming that broadband providers enjoy a minimal First Amendment interest in the transmission or conduit functions they perform, a nondiscrimination mandate would be analyzed and upheld by courts as a content-neutral regulation of speech that survives intermediate scrutiny. ${ }^{23}$ In Turner Broadcasting Systems v. FCC, cable network operators objected to "must carry" rules imposed by the FCC, requiring them to carry certain news and educational programming not of their choosing, and limiting their editorial discretion over the content that could be provided over their cable channels. The Court specifically rejected the analogy the cable operators sought to draw between their First Amendment rights and those of newspaper publishers. ${ }^{24}$ It held that the First Amendment editorial rights of the cable network operators were quite limited. ${ }^{25}$ And the rights of broadband providers are even more limited given the differences between the two mediums. In particular, the Court distinguished the amount and type of control that cable network operators exercise over the communications received by their subscribers from the editorial discretion exercised by newspapers. It noted that, in contrast to newspapers, cable operators enjoy "bottleneck, or gatekeeper, control over most ... programming that is channeled into the subscriber's home" and that "simply by virtue of its ownership of the essential pathway for cable speech, a cable operator can prevent its subscribers from obtaining access to programming it chooses to exclude." ${ }^{26}$ The Court concluded that the FCC enjoys the power to "ensure that private interests not restrict, through physical control of a critical pathway of communication, the free flow of information and ideas. ${ }^{27}$

While recognizing that the "must carry" rules interfered to some extent with the First Amendment rights of cable network operators, the Court ultimately held in Turner II that these regulations were justified in light of the control that cable operators exert over the free flow of information and ideas. ${ }^{28}$ It held that the challenged regulations were content-neutral and did not burden more of the cable operators' speech than necessary to further the government's important interests. ${ }^{29}$ In his concurring opinion in Turner II, Justice Breyer explained that the "must carry" regulations served the purpose of advancing 
the national communications policy of protecting "the widest possible dissemination of information from diverse and antagonistic sources" and "facilitat[ing] the public discussion and informed deliberation [that] democratic government presupposes and the First Amendment seeks to achieve.” ${ }^{30}$ Justice Breyer concluded that although there were First Amendment interests “on both sides of the equation"--as in the current net neutrality debate--the "must carry" regulations struck a reasonable balance between potentially speech-restricting consequences for cable operators and speech-enhancing consequences for members of the public. ${ }^{31}$

As in Turner II, the FCC's proposed net neutrality regulations are content-neutral regulations that would survive intermediate scrutiny. The nondiscrimination requirement that would be imposed upon the transmission component of broadband providers' services makes no reference to the type or kind of content that must be facilitated. And the free speech interests of members of the public in having broadband providers serve as neutral conduits for our communications are even more pressing than in the Turner II context. Like the regulations at issue in Turner II, but to an even greater extent, the proposed nondiscrimination regulations advance the substantial government interest of protecting the public's access to the free flow of information and ideas--including access to unpopular or controversial expression, such as that regarding abortion or medical marijuana offerings, as discussed below. ${ }^{32}$ Even if broadband providers were able to convince a court that their First Amendment interests were implicated by such regulation--and they are implicated far less than cable operators' interests in Turner II--Turner II would counsel in favor of holding that such interests were outweighed by the countervailing free speech interests that promote broad information dissemination, public discussion, and deliberation. ${ }^{33}$ The predominant free speech interests implicated by the nondiscrimination mandate are those of members of the public--end users and content providers-in nondiscriminatory transmission of the expression they seek to send and receive, not those of the broadband providers in providing general broadband Internet access. The public's free speech interests outweigh whatever minimal editorial rights might be asserted by broadband providers with respect to the transmission component of their services, and therefore a nondiscrimination rule imposed by the FCC would not violate the First Amendment rights of broadband providers.

\section{WIRELESS BROADBAND: TRANSPARENCY ALONE IS INSUFFICIENT}

The FCC and the Verizon-Google proposal both suggest that wireless broadband Internet access providers should be immune from nondiscrimination regulations imposed on wireline broadband providers and that they should be subject only to a disclosure or transparency-in-discrimination requirement. This means that a wireless broadband provider would be permitted, for example, to cut a deal with YouTube that allowed its videos to stream faster than a video on Hulu--or even to block Hulu or other disfavored content or applications entirely--so long as the provider somehow disclosed to its subscribers that it was doing so. The justifications for this exception to the nondiscrimination mandate primarily rest on the grounds that the wireless market is comparatively more competitive than the wireline market, and that wireless networks share comparatively more limited capacity, which necessitates more active management by wireless carriers. ${ }^{34}$ These arguments for exempting wireless from the nondiscrimination mandate, however, suffer from some of the same flaws as the argument advanced by the FCC when it exempted cable broadband from nondiscrimination regulation a decade ago, as discussed above. ${ }^{35}$ And, as before, this approach will lead to the same problems.

A mere disclosure mandate, without a nondiscrimination mandate, is insufficient to protect Internet users' free speech interests with respect to wireless broadband Internet access. A disclosure mandate would merely help to facilitate a market for competition among wireless providers. Even assuming that we should entrust our First Amendment values to the market, the disclosure requirement would be insufficient to protect these values because the imperfect market conditions in the wireless market render meaningful market discipline unlikely. But more importantly, First Amendment values are quintessentially nonmarket values that cannot be adequately protected by the market in any case.

First, it is unclear whether a disclosure mandate would have any effect at all. If the duty to disclose what content you are discriminating against or blocking merely involves inserting another line in an already lengthy terms of service contract that no subscriber ever reads anyway, then such a mandate will have virtually no effect. Even if subscribers did read through wireless providers' terms of service, to meaningfully discipline a provider whose practices they disagreed with, they would need to be able easily and costlessly cancel one wireless broadband subscription and switch to another alternative service whose discrimination practices were more consistent with their own-- which they cannot do in today's market. ${ }^{36}$ 
More importantly, even assuming ease of exit and meaningful switching options, a transparency-in-discrimination requirement does not afford adequate protections for Internet users' free speech rights because such a requirement results, at best, in protection for whatever speech wins out in "the market," and does not sufficiently protect unpopular speech from discrimination. But the First Amendment's most important function is to protect speech that is unpopular, controversial, or indeed widely reviled, as I discuss below. ${ }^{37}$

As an example of discrimination against unpopular speech, consider the actions of Verizon Wireless in restricting the expression of a pro-choice organization. In 2007, Verizon Wireless refused to allow NARAL Pro-Choice America to transmit text messages to NARAL's own members. ${ }^{38}$ Asserting its authority to block messages from any group that seeks to "distribute content that, in [Verizon's] discretion, may be seen as controversial or unsavory to any of our users," Verizon initially refused to facilitate the transmission of such messages to certain users--even when those users had explicitly signed up to receive NARAL's messages..$^{39}$ In that case, Verizon ultimately bowed to public pressure (after it was subject to criticism in the mainstream media--including in a front page article in the New York Times) and reversed course (while maintaining that it enjoys the discretion to determine which text messages to facilitate and which to prohibit). ${ }^{40}$ Although the market imposed a sufficient check on Verizon's censorship under the circumstances of that case, consider the case in which the majority of the relevant public did not support the speech at issue. (Indeed, T-Mobile's recent censorship of text messages relating to legal medical marijuana services provides an example of discrimination against such controversial or unpopular content.) $)^{41}$ If a wireless provider found that there was insufficient popular support for particular "controversial" or "unsavory" (but First Amendment protected) communications, it might very well censor such expression, and a transparency requirement would not impose a sufficient check on such an action because such speech (being unpopular) could not garner sufficient popular support. And, if wireless providers enjoy the discretion to censor in this context, they also enjoy the discretion to censor content beyond text messages--including web page access, emails, and other content that is directly or indirectly under their control.

Such censorship of unpopular speech by wireless providers is inconsistent with the First Amendment. ${ }^{42}$ If there is a "bedrock principle" of the First Amendment, ${ }^{43}$ it is that government may not prohibit speech simply because "the overwhelming majority of people might find [it] distasteful or discomforting." ${ }^{44}$ Rather, the unpopularity of the speech is the very reason "for according it constitutional protection" ${ }^{45}$--including in such contexts as burning the American flag, ${ }^{46}$ depicting animal cruelty, ${ }^{47}$ cross burning, ${ }^{48}$ and similar hate speech, such as pro-Nazi speech addressed to Holocaust survivors. ${ }^{49}$ As Justice Kennedy has explained, "the creation of standards and adherence to them, even when it means affording protection to speech unpopular or distasteful, is the central achievement of our First Amendment jurisprudence." ${ }^{50}$ Because of the importance of protecting unpopular or counter-majoritarian speech within our constitutional framework, mandating transparency-indiscrimination alone for wireless broadband providers--without mandating nondiscrimination--will not suffice to protect our full panoply of free speech rights and will not serve as a meaningful check on wireless providers' discrimination against unpopular, controversial, but constitutionally protected speech. To protect this fundamental aspect of the free speech guarantee, wireless broadband providers must also be subject to a nondiscrimination mandate.

Furthermore, even assuming that a transparency-in-discrimination mandate protects the free speech interests of the would-be recipient of a blocked communication, such a requirement does virtually nothing to protect the free speech interests of the would-be speaker whose speech is blocked. If a wireless provider is merely under the obligation to disclose to a would-be speaker that his or her expression will be blocked, that leaves the speaker with no recourse to reach his or her intended audience. If, for example, Verizon Wireless were to inform NARAL of its intention to block all of NARAL's communications to its wireless Internet subscribers, NARAL would have little recourse to communicate via text or the Internet with these subscribers. Just as the would-be sender of unpopular snail mail would have little recourse if the U.S. Postal Service enjoyed the discretion to refuse to transmit its communications, ${ }^{51}$ so too does the would-be sender lack meaningful options to communicate if its wireless provider refuses to transmit its communications.

In short, even assuming counterfactually that the market conditions exist for subscribers to express meaningfully their preferences and to discipline effectively wireless providers, a transparency-in-discrimination requirement insufficiently protects the full panoply of First Amendment free speech interests.

\section{SPECIALIZED SERVICES AND A SPECIALIZED NONDISCRIMINATION MANDATE}


Both the FCC and the Verizon-Google proposed framework suggest a different regulatory approach for the provision of general broadband Internet access services, on the one hand, and the provision of "specialized" or "additional online services," on the other, in which the latter would not be subject to a nondiscrimination (or even a transparency-indiscrimination) requirement. "Specialized Services" are defined to include "additional or differentiated services [that] would have to be distinguishable in scope and purpose from broadband Internet access service" and might include a service offered by a broadband provider that was devoted to telemedicine or to online gaming that require enhanced quality of service. ${ }^{52}$ Several commentators have expressed concern that carving out specialized services and exempting them from the nondiscrimination and transparency mandates might provide an incentive for providers to migrate more of their offerings toward this unregulated category with the result that this exception would swallow the rule and there would be little left of the "neutral" part of the Internet. I share these concerns and suggest that the First Amendment public forum doctrine provides a useful framework for evaluating the free speech implications of according differential regulation to such services. Essentially, I argue that broadband providers providing general broadband Internet access services perform a role that is analogous to offering and facilitating a general public forum and should be subject to the same stringent nondiscrimination mandate as are providers of general public forums. In contrast, broadband providers providing specialized services perform a role that is analogous to offering a limited public forum and accordingly should be subject to a more limited--but still meaningful--nondiscrimination mandate, such as that imposed on providers of limited-purpose public forums under First Amendment law.

Public forums--spaces that are open to the public for purposes of communication and expression--whether in real space or cyberspace--are essential to our form of democratic self-government. Within places that have traditionally been available for expressive purposes--like public parks, streets, sidewalks, or property that has been designated for expressive purposes-- like auditoriums and concert halls--speakers are permitted to express themselves from whatever viewpoints and on whatever subjects they choose. Within these traditional, designated public forums, citizens enjoy the fullest and most meaningful protection of their right to free expression. The provider of such a public forum is required under the public forum doctrine to permit all manner of expression--regardless of the content of such speech or the viewpoint expressed within the forum ${ }^{53}$--and any restrictions on speech in these forums are subject to the strictest judicial scrutiny. ${ }^{54}$ On public streets and sidewalks and other "natural and proper places for the dissemination of information," 55 the government has no power to censor speech on disfavored topics or from unpopular viewpoints. When Jersey City sought to ban the Committee for Industrial Organization from communicating with city residents about employment-related matters on its streets and sidewalks, the Court explained that the government does not enjoy the same rights as private property owners to exclude individuals from its property; rather, our form of democratic self-government requires that the government accord citizens meaningful opportunities to express themselves, as well as meaningful venues in which to do so. ${ }^{56}$ When the state sought to prohibit individuals from leafleting in airport terminals, Justice Kennedy, undertaking a functional interpretation of the public forum doctrine, explained that open public spaces that are suitable for discourse must be conceptualized as public forums if the doctrine is to retain relevance "in times of fast-changing technology." ${ }_{57}$ The role of providers of general public forums--like streets, sidewalks, airport terminals, and other open public spaces suitable for discourse--is to facilitate communications without discrimination on the basis of content or viewpoint. Just as it is impermissible for the provider of a public forum--whether the government or a "private" entity ${ }^{58}$--to discriminate on the basis of content or viewpoint (i.e., "no political speech here" or "no Tea Party speech here"), so too it should be impermissible for providers of general broadband Internet access services to discriminate on the basis of content or viewpoint.

In contrast, the government--or a private entity like a broadband provider--may establish a public forum that is devoted to particular purposes or subjects. First Amendment doctrine provides that, within a public forum devoted to particular subjects or purposes, the provider may impose restrictions limiting expression to the particular subjects or purposes for which the forum is designated. While discrimination on the basis of viewpoint is not permitted within such limited public forums, discrimination on the basis of subject is permissible to ensure that the subject-matter confines of the forum are maintained. As the Supreme Court explained regarding the permissible types of restrictions in limited public forums:

The necessities of confining a forum to the limited and legitimate purposes for which it was created may justify the [owner, here the State] in reserving it ... for the discussion of certain topics. Once it has opened a limited public forum, however, the State must respect the lawful boundaries it has itself set. The State may not exclude speech where its distinction is not "reasonable in light of the purpose served by the forum," nor may it discriminate against speech on the basis of its viewpoint ....59 
For example, in a case where a public school district had expressly opened up its school facilities to after-hours use by members of the public for "social, civic, and recreational purposes"--including the discussion of family issues and child rearing--the district was required to facilitate expression on these topics from all viewpoints, including religious viewpoints. As the Court explained, “'although a speaker may be excluded ... if he wishes to address a topic not encompassed within the [limited] purposes of the forum ..., the government violates the First Amendment when it denies access to a speaker solely to suppress the point of view he espouses on an otherwise includible subject."” ${ }_{60}$

By analogy to the public forum doctrine, broadband providers' provision of specialized services should be subject to a rule prohibiting viewpoint discrimination and prohibiting unreasonable discrimination but allowing subject-matter distinctions where necessary and consistent with preserving "the purposes of that limited forum." ${ }^{61}$ For example, under the framework I suggest, if a broadband provider offered a specialized service devoted to medical services, it would be permissible for it to prohibit non-medical related content, but not to prohibit pro-choice or pro-birth control related medical content or applications. Knotty questions might arise, for example, if a provider sought to define the subject of a specialized service as a "Christian medical service" or a "family-friendly gaming service" and to limit content and applications to those categories. But First Amendment public forum doctrine is sufficiently well-developed to provide helpful tools for handling these complicated questions as well. ${ }^{62}$

\section{CONCLUSION}

The FCC is to be applauded for undertaking measures to impose a meaningful nondiscrimination mandate on wireline broadband Internet providers who serve as conduits for our communications in an increasingly important manner. However, the FCC should not exempt wireless providers from this mandate--even assuming that the wireless market is more competitive than the wireline market. Because free speech values are non-market values, they cannot be entrusted solely to the market--even if the market were characterized by robust competition and meaningful disclosure requirements (which it is not). To protect our free speech interests in the Internet realm, broadband providers-- both wireline and wireless--should be subject to a nondiscrimination mandate. And, while it may be permissible to carve out exceptions to the broad nondiscrimination mandate for "specialized" services, the regulation of these services should be informed by the public forum doctrine, which imposes meaningful and appropriate protections for First Amendment rights within both general and limited public forums.

\section{Footnotes}

a1 I am grateful for the tireless and insightful assistance of Rob Arcamona; the excellent comments and critiques of the Yale Law \& Policy Review editors, especially Executive Editor Christopher Suarez; and the library research assistance of Ken Rodriguez.

1 See Comcast Corp. v. FCC, 600 F.3d 642 (D.C. Cir. 2010) (holding that the FCC did not enjoy “ancillary jurisdiction” to regulate the network management practices of Comcast under its 2005 Net Neutrality Policy Statement or otherwise).

2 See Comments of AT\&T, Inc., GN Docket No. 09-191, at 235-44 (Fed. Commc’n Comm'n Jan. 14, 2010), http://fjallfoss.fcc.gov/ecfs/document/view? id=7020377217; see also Comments of Cox Commc’ns, Inc., GN Docket No. 09-191, at 4-7 (Fed. Commc'n Comm'n January 14, 2010), http:// fjallfoss.fcc.gov/ecfs/document/view?id=7020378714 (arguing that a restrained approach to regulating the Internet promotes innovation in the broadband marketplace). 
Cf. Lamont v. Postmaster Gen., 381 U.S. 301 (1965), available at http://supreme.justia.com/us/381/301/ (holding unconstitutional a law requiring the U.S. Postal Service to detain and destroy unsealed mail matter containing communist political propaganda unless the addressee returned a reply card indicating a desire to receive such mail).

See Stephanie Condon, Al Franken to Liberals: Don't Check Out Now, CBS NEW, July 24, 2010, http://www.cbsnews.com/8301503544_162-20011587-503544.html (quoting Al Franken).

See Comcast v. FCC, 600 F.3d 642, 644 (D.C. Cir. 2010).

Framework for Broadband Internet Service, GN Docket No. 10-127, Notice of Inquiry, 255 FCC Recd. 7866, at 92 (June 17, 2010), available at http://www.fcc.gov/Daily_Releases/Daily_Business/2010/db0617/FCC-10-114A1.pdf. While this document is labeled a Notice of Inquiry, given its tone and subsequent statements by current FCC Chairman Genachowski, it is appropriate to call it a "proposal."

Formerly, in the Bush years, the FCC had classified cable broadband generally (and then all other broadband) as a very lightly regulated Title I “information service.” See id. at ๆ 7; see also 47 U.S.C. § 153 (2006) (defining “information service”).

Under the Third Way proposal, the six provisions of Title II that would apply to broadband providers are: § 201 (requiring providers to interconnect and charge reasonable rates); § 202 (prohibiting price or service discrimination); § 208 (allowing the Commission to enforce these provisions and setting up FCC complaint processes); $§ 222$ (protecting customer privacy and proprietary commercial information); § 254 (allowing use of universal service fund for broadband); and § 255 (ensuring disability access). See Julius Genachowski, The Third Way: A Narrowly Tailored Broadband Framework, BROADBAND.GOV (May 6, 2010), http://www.broadband.gov/the-third-way-narrowly-tailored-broadband-framework-chairman-julius-genachowski.html. Section 202 is particularly important in this context, providing that common carriers must not "make any unjust or unreasonable discrimination in charges, practices, classifications, regulations, facilities, or services for or in connection with like communications service” and must not "make or give any undue or unreasonable preference or advantage to any particular person, class of persons, or locality ... to any undue or unreasonable prejudice or disadvantage.” 47 U.S.C. § 202(a) (2006).

See, e.g., Further Inquiry Into Two Under-Developed Issues in the Open Internet Proceeding, GN Docket No. 09-191 (Fed. Commc'n Comm'n Sept. 1, 2010) [hereinafter FCC Further Inquiry], available at http://www.fcc.gov/Daily_ Releases/Daily_Business/2010/db0901/DA-10-1667A1.pdf (discussing potential policy approaches that can address concerns about protections of specialized services).

Verizon-Google Legislative Framework Proposal, GOOGLE BLOG (Aug. 9, 2010), http://www.google.com/googleblogs/pdfs/verizon_google_legislative_framework_proposal_081010.pdf.

The qualifications are that providers would be prohibited from engaging in "undue" discrimination--with no explanation of what that term means--and that prioritization of Internet traffic "would be presumed inconsistent with the non-discrimination standard but the presumption could be rebutted.” Id. at 1.

The transparency requirement, which would apply to all three categories, would mandate that "providers of broadband Internet access ... disclose accurate and relevant information in plain language about the characteristics and capabilities of their offerings, their broadband network management, and other practices necessary for consumers and other users to make informed choices.” Id. 
See Comments of Verizon and Verizon Wireless, GN Docket No. 10-127, at 89 (Fed. Commc'n Comm'n July 15, 2010), http:// fjallfoss.fcc.gov/ecfs/document/view?id=7020544554 (noting that, given the current "highly competitive state of the broadband market, ... providers offer subscribers access to all lawful content ...”).

See Comments of AT\&T, Inc., GN Docket No. 09-191, at 235-44 (Fed. Commc’n Comm'n Jan. 14, 2010), http://fjallfoss.fcc.gov/ecfs/document/view? id=7020377217.

Comments of Verizon and Verizon Wireless, supra note 16, at 79.

Id. at 80 .

Miami Herald Publ'g Co. v. Tornillo, 418 U.S. 241 (1974).

Comments of Verizon and Verizon Wireless, supra note 16, at 80.

See Comments of Free Press, GN Docket No. 09-191, at 136-37 n.297 (Fed. Commc’n Comm’n January 14, 2010).

See Turner Broad. Sys. v. FCC, 512 U.S. 622 (1994), available at http://www.law.cornell.edu/supct/html/93-44.ZS.html.

Id. at 654-55.

Id.

Id. at 656-57 (emphasis added).

Id.

Turner Broad. Sys. v. FCC (Turner II), 520 U.S. 180 (1997).

Id. at 189-90.

Id. at 226-27 (Breyer, J., concurring).

Id. at 227.

See infra notes 38-39 and accompanying text.

See, e.g., Denver Area Educ. Telecomm. Consortium, Inc. v. FCC, 518 U.S. 727, 741 (1996) (noting the importance of upholding the Government's "respon[ses] to serious problems” in certain First Amendment contexts when those responses are "appropriately tailored to resolve those problems without imposing an unnecessarily great restriction on speech").

See, e.g., Richard Whitt, Facts About Our Network Neutrality Policy Proposal, GOOGLE PUBLIC POLICY BLOG (Aug. 12, 
2010, 1:46 PM), http:// googlepublicpolicy.blogspot.com/2010/08/facts-about-our-network-neutrality.html. Mr. Whitt is Google’s Washington Telecom and Media Counsel.

For a brief discussion of the FCC's removal of common carriage requirements from cable broadband, see note 9. Essentially, the FCC argued at that time that "broadband service should exist in a minimal regulatory environment that promotes investment and innovation in a competitive market.” Nat'l Cable \& Telecomms. Ass’n v. Brand X Internet Servs., 545 U.S. 967, 1001 (2005) (citations omitted).

The argument that government intervention in general--and a nondiscrimination mandate in particular--is unwarranted because of the existence of competition within a particular market essentially rests on the libertarian premise that if choice is available, government regulation in the public interest is unnecessary. For example, under the libertarian framework articulated by Robert Nozick in Anarchy, State, and Utopia, where individuals have the freedom to join together to form communities of common valuesets and to exit from communities that no longer reflect their value-sets, government intervention in the public interest is unnecessary. Nozick articulates two components of the libertarian utopian framework: (1) a "wide and diverse range of communities," with a corresponding wide range of value-sets adopted by such communities; and (2) a "great liberty to choose" among this wide range of communities and ease of exiting one community and entering another that better accords with an individual's value choices. ROBERT NOZICK, ANARCHY, STATE, AND UTOPIA 307, 320 (1974); see ALBERT O. HIRSCHMAN, EXIT, VOICE, AND LOYALTY: RESPONSES TO DECLINE IN FIRMS, ORGANIZATIONS, AND STATES (1974). If these characteristics of the market are present, the libertarian argument proceeds, government intervention is unjustified because individuals can be trusted to act in their best interest to exercise their freedom to choose which communities to join and which to leave, and consequently which values to be governed by. However, even positing that a wide and diverse range of wireless broadband providers with various discrimination practices is available, within the current market, subscribers do not have a "great liberty to choose," and do not enjoy ease of exit. Thus, the existence of a robust market of wireless providers is not an adequate substitute for government intervention to prevent discrimination.

See infra notes 41-49 and accompanying text.

Adam Liptak, Verizon Blocks Messages of Abortion Rights Group, N.Y. TIMES, Sept. 27, 2007, http://www.nytimes.com/2007/09/27/us/27verizon.html.

Id. (emphasis added).

See Adam Liptak, In Reversal, Verizon Says It Will Allow Group's Texts, N.Y. TIMES, Sept. 28, 2007, http:/query.nytimes.com/gst/fullpage.html? res=9D05E6DC103EF93BA1575AC0A9619C8B63; see also Comments of Public Knowledge et al., WT Docket No. 08-7 (Fed. Commc'n Comm’n Mar. 14, 2008), http:// www.publicknowledge.org/pdf/pk-etalcomments-20080314.pdf (criticizing Verizon's actions and arguing that Verizon's text messaging services are subject to nondiscrimination rules).

In September, T-Mobile blocked all text messages going to or coming from EZ Texting, a marketing company that enables its clients to provide "short code" text messaging. T-Mobile did so because EZ Texting had contracted with the Legal Marijuana Dispensary, a web service that provides information regarding access to legal medical marijuana in California and other states where it is legal. T-Mobile found the Legal Marijuana Dispensary content to be "objectionable" and accordingly sought to block all text messages to or from EZ Texting--regardless of whether the messages involved the Legal Marijuana Dispensary--even after EZ Texting agreed to drop Legal Marijuana Dispensary as a client. In response to EZ Texting's lawsuit, T-Mobile asserted that it had the discretion to refuse to facilitate content of which it did not approve. See Edward Moyer, T-Mobile Sued for Allegedly Blocking Pot-Related Texting, CNET NEWS (Sept. 18, 2010), http://news.cnet.com/8301-13578_3-20016908-38.html.

See, e.g., Virginia v. Black, 538 U.S. 343, 358 (2003) ("The hallmark of the protection of free speech is to allow 'free trade in ideas'-- even ideas that the overwhelming majority of people might find distasteful or discomforting." (citations omitted)); Simon \& Schuster, Inc. v. Members of N.Y. State Crimes Victims Bd., 502 U.S. 105, 118 (1991) ("As we have often had occasion to repeat: '[T]he fact that society may find speech offensive is not a sufficient reason for suppressing it. Indeed, if it is the speaker's 
opinion that gives offense, that consequence is a reason for according it constitutional protection.” (quoting Hustler Magazine, Inc. v. Falwell, 485 U.S. 46, 55 (1988)); Texas v. Johnson, 491 U.S. 397, 414 (1989) ("If there is a bedrock principle underlying the First Amendment, it is that the government may not prohibit the expression of an idea simply because society finds the idea itself offensive or disagreeable.”).

Johnson, 491 U.S. at 414.

Black, 538 U.S. at 358.

Simon \& Schuster, Inc., 502 U.S. at 118 (citation omitted).

Johnson, 491 U.S. at 414.

United States v. Stevens, 130 S.Ct. 1577 (2010).

Black, 538 U.S. at 358.

Nat'l Socialist Party v. Village of Skokie, 432 U.S. 43 (1977).

Denver Area Educ. Telecomm. Consortium, Inc. v. FCC, 518 U.S. 727, 784 (1996) (Kennedy, J., concurring in part, concurring in the judgment in part, and dissenting in part) (emphasis added); see also Thomas R. Marshall, American Public Opinion and the Rehnquist Court, 89 JUDICATURE 177, 178 (2005) (reporting an empirical study to conclude that, although the Rehnquist Court's decisions track public opinion on many significant constitutional issues, they do not track public opinion in First Amendment cases).

Of course, the point is that the U.S. Postal Service, as a common carrier, does not enjoy such discretion, as discussed above at text accompanying notes 4-5.

The FCC's September 1, 2010, Public Notice, for example, continues to suggest differential treatment for general versus specialized services. See FCC Further Inquiry, supra note 11. Similarly, the Verizon-Google Legislative Framework Proposal distinguishes between the provision of general broadband Internet access service and the provision of "additional or differentiated services [that] would have to be distinguishable in scope and purpose from broadband Internet access service.” See VerizonGoogle Legislative Framework Proposal, supra note 12.

See, e.g., Burson v. Freeman, 504 U.S. 191 (1992).

Schneider v. New Jersey, 308 U.S. 147, 163 (1939).

Hague v. Comm. for Indus. Org., 307 U.S. 494 (1939).

Int'l Soc'y for Krishna Consciousness v. Lee, 505 U.S. 672, 697 (1992) (Kennedy, J., concurring), available at http:// www.law.cornell.edu/supct/html/historics/USSC_CR_0505_0672_ZC1.html. 
See, e.g., PruneYard Shopping Ctr. v. Robins, 447 U.S. 74 (1980) (upholding against constitutional challenge a state constitutional provision that essentially required private shopping centers to serve as public forums); Marsh v. Alabama, 326 U.S. 501 (1946) (treating a private entity that managed a town and that exercised the power to regulate the free flow of information within its property as the equivalent of the state for First Amendment/public forum purposes and prohibited this private entity from censoring speech). In Robins, the Supreme Court held that a provision of the California Constitution that prohibited private shopping malls from excluding speakers did not violate the shopping mall's free speech or property rights, where the mall owners had expressly thrown their property "open to the public to come and go as they please" and had not "limited [it] to the[ir] personal use.” Robins, 447 U.S. at 87.

Rosenberger v. Rector \& Visitors of the Univ. of Va., 515 U.S. 819, 829 (1995) (emphasis added) (citations omitted).

Lamb’s Chapel v. Center Moriches Union Free Sch. Dist., 508 U.S. 384, 394 (1993) (emphasis added) (quoting Cornelius v. NAACP Legal Def. \& Educ. Fund, Inc., 473 U.S. 788, 806 (1985)).

Rosenberger, 515 U.S. at 830.

See, e.g., id. (holding that a university's attempt to define a limited public forum as including only student publications that do not manifest a particular belief in or about a deity or an ultimate reality was not a constitutional limitation on the scope of the forum and instead constituted unconstitutional viewpoint discrimination); Hopper v. City of Pasco, 241 F.3d 1067, 1068 (9th Cir. 2001) (finding that a city, upon creating a public forum for the display of artwork, violated the First Amendment when it censored "controversial" works, notwithstanding the city's argument that it intended to create a limited public forum only for "uncontroversial” artwork), available at http://openjurist.org/241/f3d/1067/janette-hopper-sharon-rupp-v-city-of-pasco-artscouncil-of-the-mid-columbia-region. 